\title{
The Correlation Between Self-Control and Social Media Addiction (Instagram) In SMA Harapan 1 Medan
}

\author{
Anna Wati Dewi Purba ${ }^{1 *}$, Istiana ${ }^{2}$, Nini Sri Wahyuni ${ }^{3}$ \\ ${ }^{1,2,3)}$ Faculty of Psychology, Universitas Medan Area, Indonesia \\ *awdp1966@gmail.com
}

\begin{abstract}
The objective of this study is to find the correlation between self-control and social media addiction (Instagram) of teenagers. This research uses a quantitative approach, and samples a total of 62 teenagers in the XI class in SMA Harapan 1 Medan, with purposive sampling. Data retrieval is done using two scales, namely self-control and social media addiction (Instagram). Data analysis using product moment correlation techniques with $\mathrm{r}_{\mathrm{xy}}=-0.419 ; \mathrm{p}=0.000<0.05$, meaning that there is a negative correlation between self-control and social media addiction, which indicates that the higher the self-control then the lower the social media addiction. Instead, the lower the self control then the higher the social media addiction. Thus the hypothesis proposed is accepted. Based on the research result, the contribution self-control in social media addiction is $17.6 \%$ and the rest is $82.4 \%$ affected by other factors
\end{abstract}

Keywords: self control, social media addiction, teenagers

\section{Introduction}

Technological developments in this globalization era have a real impact on human life. People are helped by facilities and infrastructure that are increasingly sophisticated compared to previous civilizations and are further facilitated by the increasing access to search for information that is practical and fast which is called The Internet. The internet can be accessed by all people from children to adults. Among the teenagers, the internet is no longer a stranger, so that most of the teenagers looking for references or teaching and learning needs by just simply accessing the internet. The internet is used to obtain various information ranging from science and education, health, news and so forth.

The internet is also practical and fast and also it is really easy to used. From the internet, people can get and use various kinds of social media. Social media is a form of online media or cyberspace, where users can easily participate and share information that is used to socialized, both personally, in groups and so forth between users. Basically social media can be considered as one of a kind kinds of communication media.

These days, Instagram is become one of the biggest social media platform with a big number of user. Instagram users are sharing everything actively about their daily lifes by taking photos, videos, or another content and uploading them on their account. The content are created by themselves and they shared it in order to express their personality and self. Beside sharing the content they create, they can also share the content that they like from other's account. People are getting more comfortable on social media because the content on 
Instagram is getting more interesting. Technology provides new effects for humans in socializing and has become a platform for socializing in the community [1].

Based on the findings from a research and analysis company from the United Kingdom Taylor Nelson Sofres (TNS), the most active Instagram users are teenagers $(59 \%)$ and Indonesia is ranked 3rd as a country with most active instagram users . As we know adolescence is a phase of development of the transition between childhood into adulthood which also involves biological changes. Santrock [2] said that adolescents are also filled with a period of storm and stress, where in this phase the emotions of adolescents are unstable which filled with conflict and uncertain moods.

Teenagers at the stage of storm and stress are very much influenced by their environment, which makes the social media becomes a tool to express themselves. The teens think that by accessing Instagram they can eliminate boredom and transfer some of their stress and even some teenagers feel uneasy when they can not accessing their Instagram account [3]. The thing is, teenagers are busy by themselves with their smartphones, sharing their status or make comments on their respective Instagram pages while they are still walking together with their friends, and somehow Instagram is become a necessity in their life.

The presence of Instagram in the community, especially among teenagers or students somehow has a negative impact, especially if it is used excessively. Negative symptoms that appear from the use of Instagram in the world of education are making the students wasting their times in playing Instagram and forget their activities as a student, they can't manage their time, becoming lazy to learn or to do an activity like doing a daily task because they are more interested in opening Instagram due to checking or finding information or the latest news. Therefore, using Instagram without limits and without remembering the time can make teens become addicted. Addiction to Instagram is included in the internet addiction to friendship sites in cyberspace (Cyber Relational Addiction) which causes the worst impact or influence of Instagram for the world of education, decrease the interest and learning achievement due to an addiction.

Online addicts feel a sense of changing when they spend their time online and are unable to manage the main aspects of an individual's life because the individual is preoccupied with online stuff [4]. Individuals start losing the important periods at work and spending less time with family. Individuals neglect social relationships with individual friends, coworkers, and with individual communities, and eventually their lives become out of control. The addiction of using Instagram makes us have such as lack of interaction with the surrounding environment and tend to ignore friends because it is the only thing we focused on and make us forgetting time in doing assignments, feeling lazy to learn, having feelings of anxiety when a new notification comes in, and lack of sleep resulting in lazy to get up early to go to school due to wake up too late because of playing Instagram.

The results of research released by the Faculty of Nursing Airlangga University that $83 \%$ of adolescents suffer from dependency of social media, especially Instagram, makes them unable to escape from social media even for just a day, this certainly also causes disruption to the learning process for students because a distracted attention can disrupt the learning process due to not being able to control and have an impact on the ability to concentrate [5]. In addition, several research conducted of Public Health to nearly 1,500 teenagers, Instagram became one of the worst social media for mental health and well-being because Instagram has the potential to create anxiety for its users, low self-confidence, potentially creating bullying and FOMO (fear of missing out) practices, as well as loss of self control, therefore this research results suggest that Instagram use is limited to not more than 2 hours per day [7]. 


\section{Research Method}

This study uses a quantitative approach. A quantitative approach used in this research proposals to processes, hypotheses, down to the field, data analysis and data conclusions up to writing using aspects of measurement, calculation, formula and certainty of numeric data. Arikunto [8] explains that quantitative research is research that uses a lot of numbers, starting from data collection, interpretation of data and the appearance of the results.

The operational definitions of each of the research variables are as follows: Self-Control: It can be concluded that self-control is a collection of individual abilities to be able to guide, organize and direct themselves so that it leads to positive consequences. Self-control is arranged based on the characteristics revealed by Thompson that is the ability to control a behavior, ability to delay gratification and ability to anticipate events. Social media addiction is behavior that is carried out continuously in playing social media in which its users add the number of another user so that it is difficult to be limited. Addicted to social media (Instagram) based on the characteristics compiled [4], are thinking about activities online, wanting to use the internet in increasing time to get satisfaction, unable to control, reduce or stop using social media, feel restless, depressed, depressed or irritable when reducing the activities of using social media, as well as coping from problems.

In each study, population and sample are the most important things to be able to measured. Sugiyono's research said that population is a generalization area that consists of objects / subjects that have certain qualities and characteristics that are determined by researchers to be studied and then drawning the conclusion. Then it can be concluded that the population is all subjects or individuals generalized by researchers so that conclusions can be drawn [9]. The population of the study was the 230 students of class XI of SMA Swasta Harapan 1 Medan.

The sample is part of the number and characteristics possessed by the population, have the same characteristics so that the results of research on the sample can be generalized to the entire population $[8,10]$. This study used a sample collection technique that is Purposive Sampling. Purposive Sampling based on specific objectives by taking into the characteristics of social media addiction (Instagram) account: Aged 15-18 years, teens who actively use social media Instagram, access social media Instagram more than 3 hours / day. The sample in this study was 62 people. Data analysis method that used was the Pearson product moment correlation technique.

\section{Results and Discussion}

Based on the results of testing the measuring instrument, it is known that the Self-Control scale of 36 items contained 2 items which were numbered 14 and 15 items, while valid of all and the corrected value aitem-total correlation moves from $r_{b t}=0.311$ to $r_{b t}=0.820$. Then it proceed with the reliability analysis (reliability test) using the Cronbarch's Alpha formula. The reliability index obtained was $\mathrm{r}=0.918$. Based on the reliability index, the scale that was compiled in this study was declared reliable.

While the Social Media Addiction scale (Instagram) of 30 items show that there are 2 items that fall, namely item number 7 and 17, and valid another items and the corrected aitemtotal correlation value moves from $r_{b t}=0.309$ to $r_{b t}=0.826$. Then proceed with the reliability analysis (reliability test) using the Cronbarch's Alpha formula. The reliability index obtained was $r=0.918$. Based on the reliability index, the scale that was compiled in this study was declared reliable. 
This study used a try-out system, which means that the data that has been taken in the measurement scale retrial is used as data for hypothesis testing. Normality test is carried out using the Kolmogorov-Smirnov method. The data is said to be normally distributed when it shows $\rho>0.05$. The self control data obtained $\rho=0.06$. This result shows that the spread of self control data is normally distributed. For social media addiction data (Instagram) obtained $\rho=0.241$, this result also shows that the distribution of social media addiction data (Instagram) is normally distributed.

Linearity test is used to determine the degree of relationship between independent variables with the dependent variable in this study, which is whether self-control has a relationship with social media addiction (Instagram). As the result with $\rho<0.05$, it can be stated to have a degree of linear relationship [10].

The variable correlation test showed a correlation coefficient of $r=-0.419 ; \rho=0,000$ $<0.05$. This shows the null hypothesis (Ho) is rejected and the alternative hypothesis (Ha) is accepted, which shows a negative relationship between self-control owned by adolescents, assuming the higher the self-control, the lower the social media addiction (Instagram). Conversely, the lower the self-control teenagers have, the higher the social media addiction (Instagram). Then it can be stated that the coefficient of determination which is obtained in this study (r2) is 0.176 . This figure means that in this study, self-control has an effective contribution of $17.6 \%$ towards Instagram social media addiction. From this percentage contribution it is known that there are still $82.4 \%$ influence of other factors on social media addiction (Instagram) in adolescents. However, this study is not including the social environment (changes in the situation) factors, motivational factors and individual personality factors themselves, lack of activity, stress or depression and lack of attention from the people around.

The results from this study are based on self-control variables in which the hypothetical mean (85) is smaller than the empirical mean (101.77) with a difference of SD $=8.996$ indicating that adolescents have a high level of self-control. The teenagers have a low social media (Instagram) addictions with a hypothetical mean (42) greater than the empirical mean (38.68) with a difference in $\mathrm{SD}=2.136$. The high self-control and low addiction to social media (Instagram) in adolescents due to the internet or social media (Instagram) in a psychological perspective is not an addiction anymore but a basic need that is part of the lifestyle to fulfill the psychological needs of individuals in their activities, especially as a tool to help the communication problems due to the limitations of distance, space and time. In this case, Instagram is a fulfillment of needs that cannot be denied in this information era because Instagram is used as a forum for the public, especially in adolescents as a medium of selfactualization to show their existence in the eyes of others.

Although Instagram social media includes psychological needs, self-control is also the most necessary thing for users to avoid the many negative impacts presented by Instagram, such as in dealing with cyberspace in order to avoid conflicts or misunderstandings that could have occurred. In addition, Instagram also has a feature for users to limit the use of the application by doing some setting activities.

This study is also supported by previous research conducted by Muna and Astuti [12] regarding the relationship between self-control and the tendency of social media addiction in late teens where the results of this study indicate that there is a negative relationship between self-control and the tendency of social media addiction in late teens . Individuals who have high self control are able to control their behavior and resist temptations that arise within themselves so that they can take an action to achieve the results that they want and avoid 
undesirable consequences. Hasil penelitian ini juga sejalan teori dan penelian terdahulu seperti Essau [12], Daryo [13], Ghufron [14] dan Borba [15].

\section{Conclusion}

Guided by the results and discussions that have been made, the following conclusions can be concluded:

1) There is a very significant negative relationship between self-control and social media addiction (Instagram). This result is proven by the correlation coefficient rxy $=$ $-0.419 ; \rho=0,000<0.05$. That is, the higher the teen's self control, the lower the social media addiction (Instagram) in adolescents. Conversely, the lower the self-control of adolescents, the higher the social media addiction (Instagram) of adolescents. Based on these results, the hypothesis that has been proposed in this study, was accepted.

2) The coefficient of determination obtained in this study is equal to $\mathrm{r} 2=0.176$. This figure means that in this study, self control has an effective contribution of $17.6 \%$ towards social media addiction (Instagram). From this percentage contribution it is known that there are still $82.4 \%$ influence of other factors on social media addiction (Instagram) in adolescents.

Self-control owned by teenagers is quite high. This is obtained from the self-control where the hypothetical mean (85) is smaller than the empirical mean (101.77) with a difference of SD $=8.996$ indicating that adolescents have a high level of self-control. However the teens have low social media (Instagram) addictions with a hypothetical mean (42) greater than the empirical mean (38.68) with a difference of $\mathrm{SD}=2.136$.

\section{References}

[1] Lewis, B. K. (2010), Social Media and Strategic Communication Attitueds and Perceptions Among College Students. Public Relation Journal, 4(3).

[2] Santrock, J. W. (2013), Life-span Development $\left(14^{\text {th }}\right.$-ed). NewYork: McGraw-Hill Companies, Inc.

[3] Aryaguna, P. (2012), Analisis Faktor Pendorong Remaja Dalam Penggunaannya Terhadap Media Jejaring Sosial: Twitter. Surabaya:Fakultas Psikologi Universitas Surabaya.

[4] Ma, H. K., Li, C. S., and Pow, J. W. C.(2011), The relation of internet use to prososial and antisosial behavior in Chinese adolescents, Cyber Psychology, Behavior and Sosial Networking, 14 (3), pp. 23-130.

[5] Montag, C. and Reuter, M. (2015), Internet Addiction, Neuroscientific Approaches and theurapeutical Implications Including Smartphone Addiction (2 $\left.2^{\text {nd }}-E d\right)$. Switzerland: Springer International.

[6] Aroma, I.S., \& Suminar, D. R. (20120, Hubungan Antara Self Control Dengan Kecenderungan Perilaku Kenakalan Remaja. Jurnal Pendidikan dan Perkembangan, 1(2), pp.1-6. 
[7] Mark, D. F., Murray, M., Evans, B. \& Willig, C. (2004), Health Psychology :Theory, Research and Practice. London: Sage Publication ltd.

[8] Arikunto, S. (2002), Metodologi Penelitian Suatu Pendekatan Proposal. Jakarta: PT. Rineska Cipta.

[9] Azwar, S. (2013), Metode Penelitian. Yogyakarta: Pustaka Pelajar.

[10] Hadi, S. (2004), Metodologi Research IV. Yogyakarta: Andi Offset.

[11] Muna, R. F. \& Astuti, T. P.(2014), Hubungan Antara Kontrol Diri dengan Kecenderungan Media Sosial Pada Remaja Akhir, 3(4).

[12] Essau, C. A. (2008) Adolescent Addiction :Epidemiology, Assesment and Treatment. New York : Elsevier Inc.

[13] Dariyo, A. (2004), Psikologi Perkembangan Remaja. Bogor Selatan: Penerbit Ghalia Indonesia.

[14] Ghufron, N and Risnawati, R. (2011), Teori-teori Psikologi. Jogjakarta: Ar-Ruzz Media.

[15] Borba, M. (2008), Membangun Kecerdasan Moral, Tujuh Kebajikan Utama Agar Anak Bermoral Tinggi. Jakarta: PT. Gramedia Pustaka Utama. 